\title{
First report of Xanthomonas citri Subsp. Citri causing citrus canker on grape fruit (Citrus paradisi), washington naval (Citrus sinensis), kaghzi limon (Citrus aurantifolia Swingle), lemon (Citrus limon) and pomelo (Citrus maxima) in Pakistan
}

\author{
Muhammad Shah Nawaz ul Rehman ${ }^{1}$, Iram Liaqat ${ }^{5}$, Javeria Nehal ${ }^{1}$, Adeel Riaz ${ }^{1}$, Nazia Nahid ${ }^{4}$, \\ Muhammad Ahsan Iqbal ${ }^{3}$, Nisar Ahmed ${ }^{1}$, Ayesha Younus ${ }^{2}$ and Muhammad Mubin ${ }^{1, *}$
}

\begin{abstract}
${ }^{1}$ Virology Lab, Centre of Agricultural Biochemistry and Biotechnology, University of Agriculture, Faisalabad, Pakistan,
${ }^{2}$ Laser Matter Interaction and Nano-sciences Lab, Department of Physics, University of Agriculture, Faisalabad Pakistan, ${ }^{3}$ Department of Plant Breeding and Genetics, University of Agriculture, Faisalabad Pakistan, ${ }^{4}$ Department of Bioinformatics and Biotechnology, GC University Faisalabad, Pakistan, ${ }^{5}$ Microbiology Laboratory, Department of Zoology, GC University, Lahore, Pakistan

*Corresponding author's e-mail: mmubin@uaf.edu.pk
\end{abstract}

\begin{abstract}
Citrus fruit production is largely affected by different bacterial and fungal pathogens. In Pakistan bacterial diseases like citrus bacterial canker (CBC) pose severe risk to citrus economy. Diagnoses of such diseases could be helpful to avoid the epidemics in nurseries or orchids. In 2011-12, citrus canker symptoms i.e., callus-like outgrowths on leaves and fruits of grape fruit (Citrus paradisi), Washington naval (Citrus sinensis), Kaghzi Limon (Citrus aurantifolia swingle), lemon (Citrus Limon) and pomelo (Citrus maxima) were noticed in Sargodha district of Punjab, Pakistan. Bacteria i.e., yellow mucoid, Xanthomonaslike isolates, were isolated from these lesions. Bacteria isolated from these lesions were cultured and total DNA was isolated. A diagnostic fragment of $581 \mathrm{bp}$ based on rpf genes of Xanthomonas citri pv. citri was amplified, cloned and completely sequenced. BLAST and evolutionary analysis revealed that these isolates show $100 \%$ sequence similarity and group with Xanthomonas citri subsp. citri from Argentina (CP023285) and Reunion (CP018858), (CP018854). To our knowledge, this is the first formal report of $X$. campestris pv. citri pathotypes A on Citrus paradise, Citrus sinensis, Citrus maxima, Citrus Limon and Citrus aurantifolia swingle in Pakistan
\end{abstract}

Keywords: Citrus paradise; Citrus sinensis; Citrus aurantifolia swingle; Citrus Limon; Citrus maxima; Xanthomonas citri pv. Citri; rpf genes; pathogenicity test.

\section{INTRODUCTION}

Among fruit crops, Citrus (Family: Rutaceae) is major fruit crop worldwide both area- and production-wise (Hynniewta et al., 2011). Lime, grapefruit, lemon and tangerines are preferred cultivars among cultivated species (Hynniewta et al., 2011). Top citrus fruits producing countries are China, United States of America, India, Brazil and Spain (Liu et al., 2012) while Pakistan is at $13^{\text {th }}$ position. In Pakistan out of five provinces, Punjab contributes a major share in terms of production as well as area (Economic survey of Pakistan, 2012). Pests and diseases majorly affect citrus yield in Pakistan and per hectare yield is low as compared to countries with well-managed orchids (Economic survey of Pakistan, 2012). In tropical and subtropical areas like Pakistan, bacterial disease of citrus i.e., citrus bacterial canker (CBC), pose a severe risk to citrus economy (Bansal et al., 2017; Gottwald et al., 2002; Polek, 2007). CBC characterized by callus-like outgrowths on leaves and other parts of the plant like fruits and twigs, is caused by Xanthomonas citri pv. citri (Gabriel et al., 2000). Due to widespread and damaging nature, severity of this disease, farmers have eradicated orchids in many countries (Bansal et al., 2017; Gottwald et al., 2002). Xanthomonas. citri pv. citri causes infection in multiple citrus species i.e., Citrus aurantifolia, C. latifolia, and C. macrophylla, and C. paradisi (Gottwald et al., 2002; Ference et al., 2017). Three types of CBC i.e., Asiatic type, Cancrosis B and Cancrosis $\mathrm{C}$ caused by $X$. axonopodis pv. citri (Xac), X. axonopodis pv. aurantifolii and X. axonopodis pv. aurantifolii prevail in the world (Das, 2003; Gottwald and Graham, 2000). Asiatic type canker is very severe form of

Rehman, M.S.N.R, I. Liaqat, J. Nehal, A. Riaz, N. Nahid, M.A. Iqbal, N. Ahmed, A. Younus and M. Mubin. 2021. First report of Xanthomonas citri Subsp. Citri causing citrus canker on grape fruit (Citrus paradisi), Washington naval (Citrus sinensis), kaghzi limon (Citrus aurantifolia Swingle), lemon (Citrus limon) and pomelo (Citrus maxima) in Pakistan. Pak. J. Agri. Sci. 58:1373-1377.

[Received 15 Oct 2019; Accepted 25 May 2021; Published (online) 21 Sep 2021] (C) (1) 
canker and is present in all citrus growing countries of the globe.

Accurate and timely detection of the $X$. axonopodis pv. citri is important to design resistant strategies against CBC. Detection of several pathogens is usually based on strain features, physiology and bacterial sensitivity (Schaad, 1988; Civerolo, 1984; Goto et al., 1980), antibody based and DNA homology based identification, and different other techniques like restriction fragment length polymorphism (RFLP) and polymerase chain reaction (PCR) (Cubero and Graham, 2002; Miyoshi et al., 1998). We have designed this study to detect the pathogen in canker lesion, so that we can take measures to prevent the further spread of pathogens.

\section{MATERIALS AND METHODS}

Sample collection and DNA extractions: In 2011-12, infected leaf samples showing symptoms of callus-like outgrowths on grape fruit (Citrus paradisi), Washington naval (Citrus sinensis), Kaghzi Limon (Citrus aurantifolia swingle), lemon (Citrus Limon) and pomelo (Citrus maxima) were collected from district Sargodha, Punjab province of Pakistan. Asymptomatic samples were collected as negative control. Before extraction of DNA leaves and fruits were washed with distilled water then dried and cleaned with tissue paper. Infected portion of the sample was cut and put in an Eppendorf tube and immediately, placed on ice and properly labeled. DNA was also extracted on the same day of sample collection. Modified CTAB method (Jaufeerally-fakim and Dookun, 2000) was used to isolate total genetic material from the leaves and bacterial culture.

Isolation and culturing of bacteria causing citrus bacterial canker: Surface sterilized leaf was placed on clean tissue paper in laminar flow cabinet and sprayed $70 \%$ ethanol both side. Then leaf lesion was wiped with tissue paper and dried. Leaf lesion was placed in sterile petri plate. Sterile scalpel blade was used to halve and then quarter the excised lesion. Four pieces of lesion of same sample were placed on nutrient agar (NA) plate. NA agar plates were properly labeled with sample number and date. Plates were incubated in $28^{\circ} \mathrm{C}$ for 7 days. For sub-culturing bacteria were streaked again to new NA agar plates. Sub-culturing was done 3 times to obtained pure culture bacteria. When pure pale yellow colonies were obtained, a single colony was picked and cultured into $5 \mathrm{ml}$ liquid NA culture.

PCR-based amplification of CBC pathogens: Amplification of diagnostic DNA fragment of pathogen from suspected samples was established using pathogen specific diagnostic primers Xac01 and Xac02 (da Silva et al., 2002). PCR reaction conditions were optimized to amplify the DNA from Xanthomonas axonopodis pv. citri strain as described by (da Silva et al., 2002). Amplification via PCR was confirmed by loading $5 \mu$ of PCR products in $0.8 \%$ agarose gels in prepared in $0.5 \mathrm{X}$ TBE buffer and visualized in IRMECO gel documenting system.

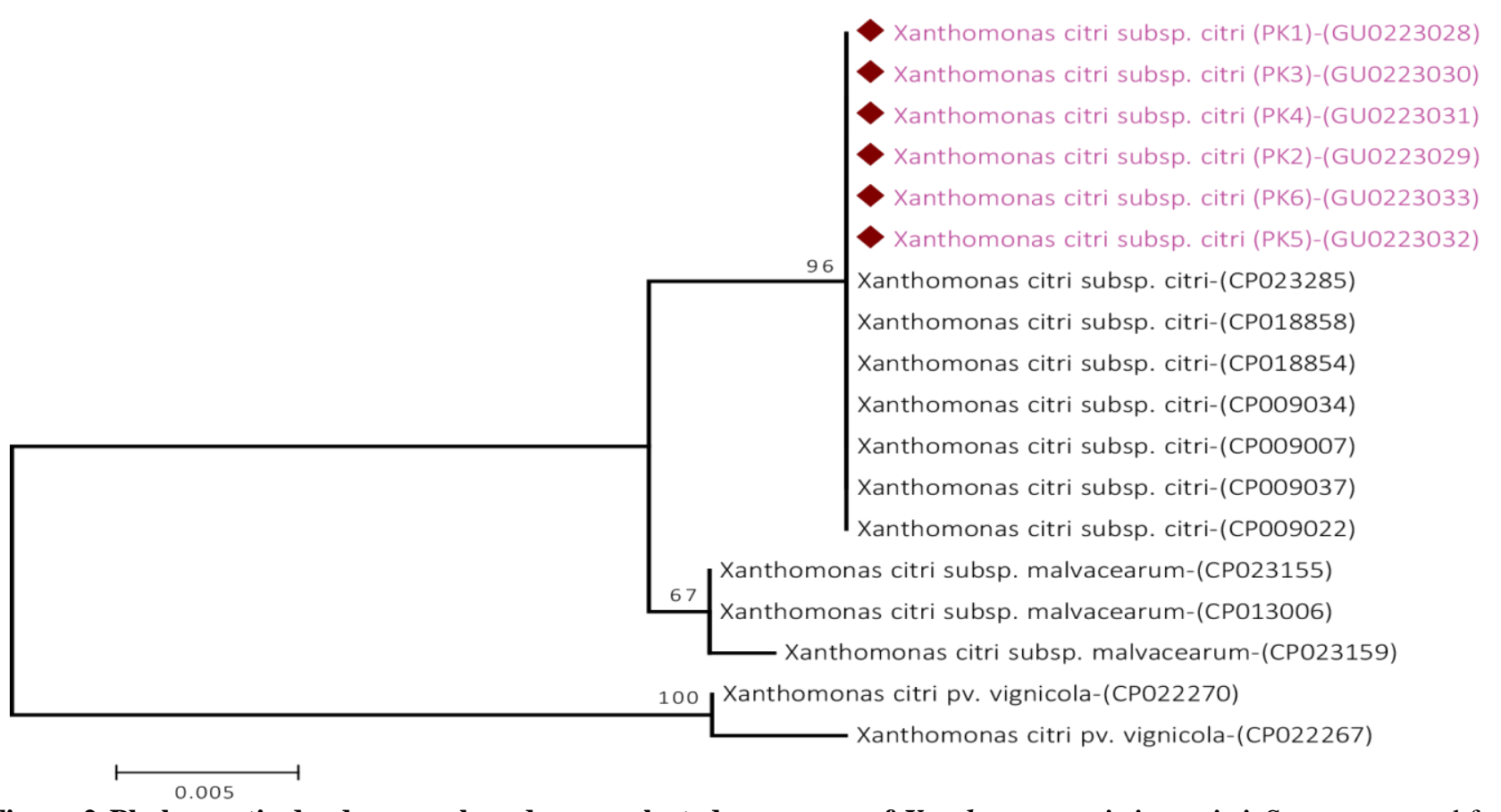

Figure 2.Phylogenetic dendrogram based upon selected sequences of Xanthomonas citri pv. citri. Sequences used for comparison were downloaded from GenBank. The database accession number in each case is given. The sequences of isolates from present study are indicated by pink color and square shape. 
Sequence and phylogenetic analysis: Vector i.e., pTZ57R/T (Fermentas) was used to clone PCR amplified fragment from each sample and completely sequenced (Sanger et al., 1977). For phylogenetic analysis all sequences i.e., isolates from this study and sequences of other closely related strains of almost same size downloaded from databank. DNA STAR software (v8; Madison, WI, USA) was used to assemble and analyze these sequences. Evolutionary trees were generated to study phylogeny, first by the alignment of sequences using CLUSTAL W that was followed by Neighbor joint method to construct phylogenetic trees using MEGA7 program (Kumar et al., 2016).

\section{RESULTS AND DISCUSSION}

Due to low quantity and quality of citrus fruit, Pakistan receives fewer prices in international market as compared to countries with well-managed citrus orchids. Pakistan is far behind in average citrus yield per hectare in comparison with other citrus producing countries. Bacterial diseases like citrus greening and citrus canker, are responsible for $35-45 \%$ yield losses and sometimes in severe disease condition no yield at all. In 2011-12, a survey was conducted of different orchids of Sargodha and severe bacterial canker disease was observed at different citrus cultivars. Infected leaf samples of grape fruit (Citrus paradisi), Washington naval (Citrus sinensis), Kaghzi Limon (Citrus aurantifolia swingle), lemon (Citrus Limon) pomelo (Citrus maxima) were collected from district Sargodha, Punjab province of Pakistan. Samples were collected from three infected plants of each cultivar from different orchid. Pathogen isolations from lesions were done using nutrient agar (NA) at $25-30{ }^{\circ} \mathrm{C}$ from all citrus cultivars, and yellow mucoid, Xanthomonas-like isolates were selected. These bacteria showed no morphological difference from pathogens already reported (Richard D et al., 2017). These bacteria were cultured and total genetic material was separated from these bacteria and subjected to PCR amplification. The specific primers $\mathrm{Xac01}$ and $\mathrm{Xac02}$ (da Silva et al., 2002) designed on rpf genes of Xanthomonas citri, were used to PCR amplify a fragment of $581 \mathrm{bps}$ from bacterial isolates. Amplified fragment from each sample was cloned in pTZ57R/T vector (Fig. 1B, C) and completely sequenced (Sanger et al., 1977). Sequence analysis showed that all bacterial pathogen isolates were $X$. citri pv. citri and 99-100\% similar with each other. This high sequence homology found between the isolates is correlated with other published reports where similar results were found (Bui et al., 2009; Carvalho et al., 2005; Cubero et al., 2002). As grafting is used to propagate economically important citrus cultivars like $C$. paradise and $C$. sinensis worldwide at a large area, there is less genetic diversity found in the $X$. citri population globally (Graham et al., 2004). Due to genetic similarity of the host plant there is less selection pressure on the pathogen.
All six sequences were submitted to GenBank with acc \# GU0223028 to GU0223033. BLAST analysis revealed that amplified region showed $100 \%$ sequence homology with $X$. citri pv. citri (CP023285), (CP018858) and (CP018854) (Richard D et al., 2017) reported from Argentina (South America) and Reunion (East of France). These results were quite surprising as none of these isolates show close sequence homology with isloates from near by regions like India and China. Since, it is a contagious pathogen, it is possible that it was introduced through trade between Pakistan and Americas. In phylogenetic analysis these sequences grouped together with the serotypes from South America, Reunion and USA (Fig. 2). Citrus is major fruit crop of Pakistan contributing towards GDP of the country substantially. Understanding pathogen causing citrus canker at molecular and sequence level is important step towards engineering resistance against $X$. citri $p v$ citri.

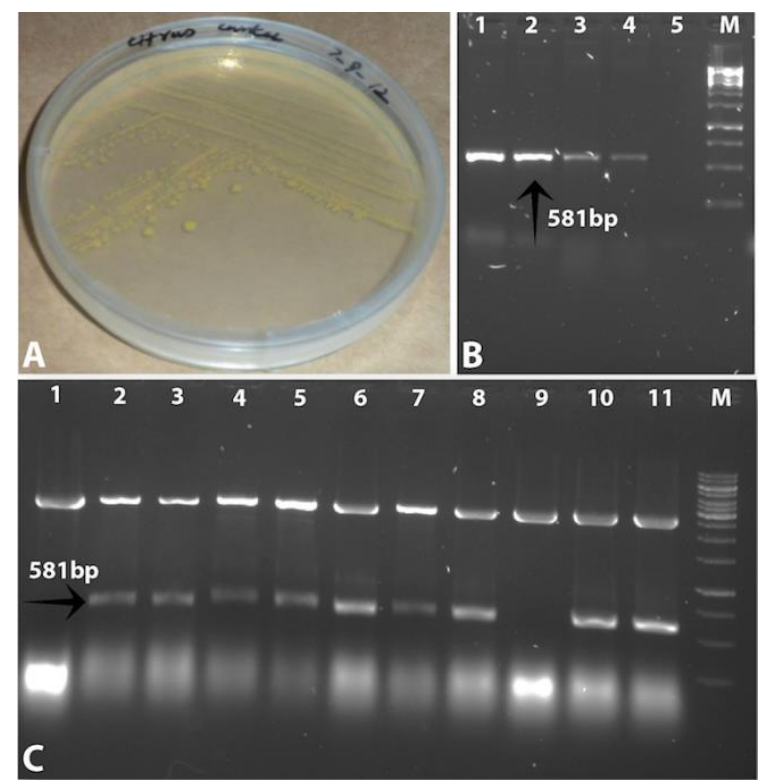

Figure 1.Bacterial isolation and cloning: A) Bacterial Isolation; A plate showing isolated yellow mucoid, Xanthomonas bacteria; B) PCR amplification of $581 \mathrm{bp}$ fragment, based on $r p f$ genes (da Silva et al., 2002), lane 1-4 PCR amplification while lane 5 is negative control; $C$ ) Cloning of amplified product into pTZ57R/T vector, lanes 2 to 8 and lane 10,11 are clones. $M$ is $1 \mathrm{~Kb}$ DNA marker (Fermentas).

The objective of this study was to provide citrus research community with information about Xanthomonas citri pv. citri infecting different cultivars of citrus in Pakistan. This is first time we are reporting $X$. citri pv. citri on grape fruit (Citrus paradisi), Washington naval (Citrus sinensis), Kaghzi Limon (Citrus aurantifolia swingle), lemon (Citrus Limon) pomelo (Citrus maxima) in Pakistan, though we were 
suspecting it for a long time. Infectivity of $X$. citri pv. citri was also established as it is important to understand how plant pathogens function in natural conditions. Sequence information plays a vital role in the identification of pathogens and increases the capacity for diagnostics.

Author's Contribution: JN, MAI, NN and AR performed all the experiments. MM, NA, MSN and AY were involved in design of the experiments and data analysis. MM, IL, MSN and AY wrote the paper while all the authors approved the manuscript.

Acknowledgement: We acknowledge all lab members for their support and cooperation in this work.

Funding: This research was supported in part by Endowment Fund Secretariat of University of Agriculture, Faisalabad, Pakistan.

Competing interests: The authors declare that they have no competing interests.

\section{REFERENCES}

Bansal, K., Midha, S., Kumar, S. and P.B. Patil. 2017. Ecological and Evolutionary Insights into Xanthomonas citri pathovar diversity. Appl. Environ. Microbiol. 17:8388.

Bhardwaj, N.R., V. Upadyay and M. Nagar. 2014. Biochemical characterization of Xanthomonas axonopodis pv. citri causal agent of citrus canker. Bioscan. 9:429-431

Bui Thi Ngoc, L.V.C., Jarne, P., Brisse, S., Guerin, F., Boutry, S., Gagnevin, L. and O. Pruvost. 2009. From local surveys to global surveillance: Three high-throughput genotyping methods for epidemiological monitoring of Xanthomonas citri pv. citri pathotypes. Appl. Environ. Microbiol. 75:1173-1184.

Carvalho, F.M.S., Caramori, P.C.L. and R.P. Leite. 2005. Genetic diversity of Xanthomonas axonopodis pv. citri based on plasmid profile and pulsed field gel electrophoresis. Genet. Mol. Biol. 28:446-451.

Civerolo, E.L. 1984. Bacterial canker disease of citrus. J. Rio Grande Valley Hortic. Soc. 37:127-146.

Cubero, J. and J.H. Graham. 2002. Genetic relationship among world- wide strains of Xanthomonas causing canker in citrus species and design of new primers. Appl. Environ. Microbiol. 68:1257-1264.

Das, A.K. 2003. Citrus canker-A review. J. Appl. Hort. 5:5260.

da Silva AC et al., 2002. Comparison of the genomes of two Xanthomonas pathogens with differing host specificities. Nature. 417:459-63
Doyle, J.J. and J.L. Doyle. 1990. A rapid total DNA preparation procedure for fresh plant tissue. Focus. 12:13-15.

Ference, C.M., Gochez, A.M., Behlau, F., 2018. Recent advances in the understanding of Xanthomonas citri ssp. citri pathogenesis and citrus canker disease management. Mol. Plant Pathol. 19:1302-1318. http://doi: 10.1111/mpp. 12638

Gottwald, T.R., Graham, J.H. and T.S. Schubert. 2002. Citrus canker: The pathogen and its impact. Online. Plant Health Prog. http://doi: 10.1094/PHP-2002-0812-01-RV

Gottwald, T.R. and J.H. Graham. 2000. Canker. In: Compendium of citrus diseases, 2nd edn. (L.W. Timmer, S.M. Garnsey and J.H. Graham, Eds.) APS Press, pp.5-8.

Goto, M., Toyoshima, A. M.A. Messina. 1980. A comparative study of the strains of Xanthomonas campestris pv. citri isolates from citrus canker in Japan and cancrosis B in Argentina. Ann. Phytopathol. Soc. Japan. 46:329-338.

Gabriel, D.W., Y.P. Duane, C. Ramadugu. 2000. The molecular mechanism of citrus canker pathogenicity and a gene engineering approach to control. Intn. Soc. Citriculture Cong. Dec. 3-7, Orlando, Florida (Abst.).pp.1-51.

Graham, J.H., Gottwald, T.R., Cubero, J. and D.S. Achor. 2004. Xanthomonas axonopodis pv. citri: Factors affecting successful eradication of citrus canker. Mol. Plant Pathol. 1:1-15.

Jaufeerally-fakim, Y. and A. Dookun. 2000. Extraction of high quality DNA from polysaccharides-secreting Xanthomonads. Res. J. Univ. Maur. 6:33-40

Hynniewta, M., Malik, S.K. and S.R. Rao. 2011. Karyological studies in ten species of Citrus (Linnaeus, 1753) (Rutaceae) of North-East India. Comp. Cytogenet. 5:277-87. doi:10.3897/CompCytogen.v5i4.1796

Kumar, S., Stecher, G. and K. Tamura. 2016. MEGA7: Molecular Evolutionary Genetics Analysis version 7.0 for bigger datasets. Mol. Bio. Evol. 33:1870-1874.

Liu, Y., Heying, E. S.A. Tanumihardjo. 2012. History, global distribution, and nutritional importance of citrus fruits. Comp. Rev. Food. Sci. Food. Saf.11:530-545. https://doi.org/10.1111/j.1541-4337.2012.00201.x

Miyoshi, T., Sawada, H., Tachibana, Y.S. and I. Matsuda. 1998. Detection of Xanthomonas campestris pv. citri by PCR using primers from the spacer region below the 16 S and 23 S r RNA genes. Ann. Phytopathol. Soc. 64:249254.

Polek, M. 2007. Citrus bacterial canker disease and Huanglongbing (Citrus greening). University of California, Agriculture and Natural Resources. DOI: 10.3733/ucanr.8218

Richard, D., Boyer, C., Vernière, C., Canteros, B.I., Lefeuvre, P. and Pruvost, O. 2017. Complete genome sequences of six copper-resistant Xanthomonas citri pv. Citri strains 
causing Asiatic citrus canker, obtained using long-read technology. Genome Announc. 5:10-17.

Sanger, F., Nicklen, S. and A.R. Coulson. 1977. DNA sequencing with chain-terminating inhibitors. Proc. Natl. Acad. Sci. 74:5463-5467.
Schaad, N.W. 1988. Laboratory Guide for Indentification of Plant Pathogenic Bacteria. APS Press, St. Paul, Minnesota. https: //doi.org/10.1046/j.13653059.2001.00635. 